\title{
Assessment of User's Perception towards Urban Green Spaces: A Case Study of Delhi, India
}

\author{
Gandherva $\mathrm{D}^{1}$, Bhattacharya $\mathrm{R}^{2}$ and Bhattacharya $\mathrm{P}^{3 *}$ \\ ${ }^{1} \mathrm{PhD}$ Research Scholar, University School of Environment Management, GGS \\ Indraprastha University, India \\ ${ }^{2} \mathrm{M}$. Phil, Indian Institute of Forest Management, India \\ ${ }^{3}$ Professor, School of Environment Management, GGS Indraprastha University, India
}

\section{Research Article \\ Volume 3 Issue 1}

Received Date: December 26, 2018

Published Date: January 24, 2019

DOI: $10.23880 /$ jenr-16000156

*Corresponding author: P Bhattacharya, University School of Environment Management, Professor, NRM GGS Indraprastha University Block-A, Sector- 16 C, Dwarka, New Delhi-110078, India, Tel: + 91-11-25196363; Email: prodyutbhattacharya@yahoo.com

\section{Abstract}

This study involved Delhi, Capital of India, which is currently experiencing two opposite phases. Delhi is one of the greenest capitals of the world yet most polluted city. At present Delhi has around $20.59 \%$ green cover which can substantially enhanced by Urban Forestry. There are more than 18000 Parks and Gardens in NCT spread in about 8000 ha in various locations. The study undertook 3 important Parks of Delhi: Lodi Garden (South Delhi), District Park, DDA, Sector 11, Dwarka (South-west Delhi) and Kamala Nehru Ridge Park, North Delhi (Proposed Biodiversity Park). The aim of the study was to analyze the important roles of Urban Green Spaces (UGS) in the life of city dwellers. Respondent's attitude towards UGS and various services provided by them was studied through a semi-structured questionnaire which has covered social, ecological and economic aspects of these places.

In total 120 respondents were selected from both parks (DDA Park and Lodi Garden) through quota sampling method and 52 respondents were randomly selected from Kamala Nehru Ridge Park, a favorite destination for morning walkers of Delhi. The study showed that more than $50 \%$ of the respondents had Willingness to Pay (WTP) for sustainable management and conservation of urban biodiversity spaces. Around $67 \%$ of the respondents didn't mind paying green tax to enjoy benefits of these places. In respondents view, most important benefit of Parks and Gardens were: they get opportunities to improve their physical health free of cost and they helps in building social ties especially for old aged adults. The results of this study struck an optimistic note that public showed WTP for conservation of UGS. Similar trends of result were shown for Kamala Nehru Ridge area. This results showed that city people doesn't neglect the importance of these Urban Green Spaces in their life as 57\% thinks that UGS has positive impact on their lifestyle.

Keywords: Ecosystem Services; Quota sampling; Ridge Forest; Urban Forestry; Urbanization; Urban Green Spaces (UGS); Willingness to Pay (WTP) 


\section{Introduction}

Delhi is an ancient as well as historical city of India. Delhi, which is located in a cusp formed by the tail end of the Aravalli Mountain Range which is $800 \mathrm{~km}$ long (elevation: 1700 meters) and 1.5 billion years old, as it culminates at the river Yamuna, is the aspirational capital of around 25 million people [1]. The hilly spurs in Delhi are known as the Delhi Ridge sometimes called "The Ridge" which once occupied almost $15 \%$ of the city's land.

Urbanization is a logical and well anticipated consequence along the development of the cities. It is an ongoing process observed throughout the world but uncontrolled urbanization without adequate environmental planning is of great concern as it may be unsustainable. The unprecedented pace of urban development has been drastically affecting man's relationship with nature [2]. In 2016, an estimated 54.5 per cent of the world's population lived in urban settlements [3]. Considering the extent of urban cluster, the National Capital Territory of Delhi stands as second largest urban area with 25 million people [1]. Urbanization is a universal trend that cannot be stopped. It brings adverse impacts with itself. Urban ecosystems draw most of important resources for its sustenance from rural areas and they are mostly man made ecosystem services. Resource manager faces challenges like comprehensive management of tree resources in urban and peri-urban areas and connection of urban people with forests and their management [4].

Urban green spaces can play significant role in sustainable development of urban settlements by providing multiple services like- improving environment through reduction of pollution, offering livelihood to the urban poor through their products and services, enhancing quality of urban life, providing places for meetings and learning etc. [5]. As per census 2011, the level of urbanization has increased from $27.81 \%$ in 2001 to $31.16 \%$ in 2011 but in 2018 , it reached to $41 \%$. The Forest Survey of India, 2013, reports urban tree cover of India as $16.40 \%$ of its total urban area and trees outside forest in urban areas have significantly contributed to it. They not only clean the urban environment but also fulfills of timber and fuel wood demands of urban poor. According to ISFR (2017), total forest cover of Delhi is 192.41 square $\mathrm{km}$ and total tree cover is 113 sq. km, hence total tree and forest cover is $305.41 \mathrm{sq}$. $\mathrm{km}$ which is $20.59 \%$ of total geographical area [6]. Per capita Forest and cover is 0.002 hectare, this is very low as per WHO norms of $9 \mathrm{~m}^{2}$ green open space per city dweller [7]. There are more than 18000 parks and gardens in National
Capital Territory (NCT) of Delhi spread in about 8000 ha in various locations [8]. Hence, these urban green spaces have the potential to convert this $20.59 \%$ of Delhi's forest cover to $33 \%$. Delhi is one of the fastest growing cities in the world, reaching over 25 million in year 2017, from just 400,000 in 1901. In 2001 alone, its population increased by 215,000 due to natural growth and 285,000 through migration. By 2020, Delhi is expected to be the third largest municipality after Tokyo and Mumbai [9]. Delhi struggles with its rapid growth and is facing substantial pressure to improve commercial and residential infrastructure [10].

Unique aspect of the notified forest in Delhi is the Ridge Land which is total $7784 \mathrm{Ha}$ of land that has been notified as Reserved Forests under section 4 of Indian Forest Act 1927. Northern Ridge consists of $87 \mathrm{Ha}$, Central Ridge consists of $864 \mathrm{Ha}$, South Central Ridge consists of $626 \mathrm{Ha}$, and $7 \mathrm{Ha}$ of the notified ridge forest land is in Nanakpura South Central Ridge. Southern Ridge Notified Forest consists of 6200 Ha [11]. A Ridge is a geological aspect that features a continuous elevation crest for some distance. The Delhi Ridge is a northern extension of the old and ancient hill ranges of India called the 'Aravalli Hill Ranges' which extend from Gujarat through Rajasthan to Haryana-Delhi [12]. The Delhi Ridge stretches over a distance of $35 \mathrm{~km}$, from Bhatti Mines to southeast of the 700 years old Tughlaqabad, branching in different directions, and finally tapering towards the northern end near Wazirabad on the western banks of Yamuna river.

Urban forestry is the management of trees for their contribution to the physiological, sociological and economic well-being of the urban society. Urban forestry deals with woodlands, group of trees and individual trees where people live. The need for urban forestry is to be planned \& integrated and systematic approach to urban tree management should be stressed. Planning is essential as trees are very often considered as reconsideration once development has taken place rather than being incorporated as original design phase. An integrated methodology implies the participation of many different organization, local council, municipal and national planning bodies, department etc. Systematic management entails regulated tree management, operations such as planting, pruning and felling must be conducted in an organized manner at the appropriate time [13].

Parks and other green spaces are the backbone of the sustainable and high quality urban environment Ecosystem services and goods has gained an enormous and steadily rising attractiveness for environmental scientists, managers etc. Urban biodiversity and green 
spaces provides a range of ecosystem services many of which are of fundamental importance to human wellbeing for health, livelihoods, and survival [14]. Some of the services provided by Urban Green Spaces are: air quality regulation, carbon sequestration, nutrient recycling, micro climate regulation, moderation of disturbances, maintain soil fertility, mitigate urban heat island effect, recreational opportunities, spiritual values, intellectual and cognitive development, tourism, aesthetic values etc. Urban green spaces includes a wide range of natural elements in urban areas such as greenways, parks, gardens, green roofs, woodlands, waterways, community farms, forests and wilderness areas that serves as an effective strategy for microscale, mesoscale, and even macroscale climate change mitigation and adaptation [15]. Figure 1 shows classification of urban green spaces. The parks and gardens are natural assets that provide a wide range of ecosystem services. Urban forests, i.e. the stock of trees in urban areas, can improve environmental conditions and quality of life in cities by providing multiple ecosystem services [16].

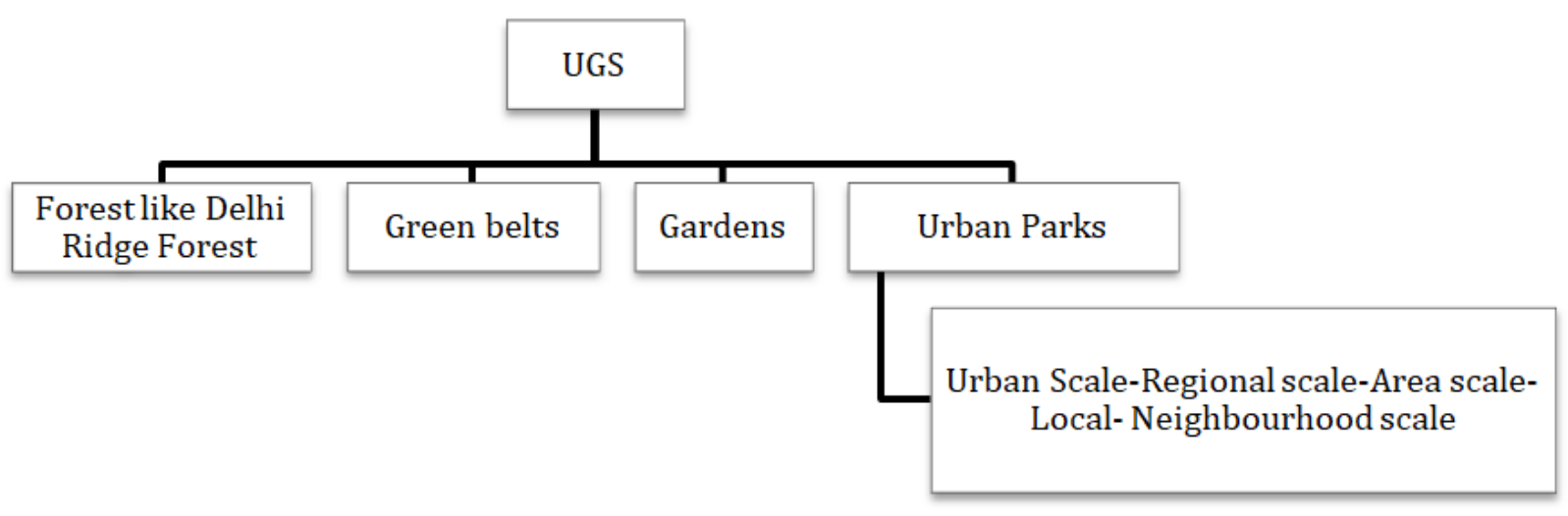

Figure 1: Classification of urban green space [17].

\section{Stakeholders of Urban Green Spaces}

The development and management of green spaces in urban areas is mostly the responsibility of governments. On the current issue of green space development and management, there is a tendency that the government is no longer the single agent. Stakeholder analysis is the process of identifying the individuals or groups that are likely to affect or be affected by a proposed action. A number of stakes are associated with this study. These are- visitors, nearby residential societies and other organizations, NGO's, policy makers, caretakers of parks, decision making authorities (Delhi Development Authority (DDA), New Delhi Municipal Council (NDMC), Resident Welfare Association (RWA), Public Works Department (PWD), Central Public Works Department (CPWD), Municipal Corporation of Delhi (MCD) etc.), Zonal Horticulture department, state Forest Department etc. The structure of stakeholder includes- state, private and society and these plays a number of roles like Management/finance, Maintenance, Implementation, and Planning/design [18].

\section{Objective}

The main objective of the study was to understand the social, ecological and economic values of urban green spaces from the point of view of residents and to assess the estimated Willingness to Pay (WTP) on the part of residents for the cause of greenery, better environment and conservation. The methods utilized here are: Contingent valuation method (CVM), Choice modeling (CM), Hedonic pricing (HP) and Travel cost method (TCM) [19].

\section{Review of Literature}

Broadly speaking, Urban Forestry is the art, science and technology of managing trees and forest resources in and around urban community for the psychological, sociological, economic, and aesthetics benefits of trees provide to society [20]. In urban setting, even small green spaces can provide high ecosystem services, if they are well planned. For example, small wetlands can improve urban hydrology by absorbing pollutants or safeguarding against flooding Pankratz, et al. [21] and vegetated 
rooftops can lessen the heating and cooling costs of buildings and slow runoff during rainstorms [22]. Green rooftops can have the added benefits of enhancing local biodiversity, not only for the initially installed plants but also for beetles, spiders, birds, and additional plants that consequently colonize the site [23]. Another significant ecosystem service is the scope for improving air quality in urban areas. In the US, urban trees annually remove 711,000 tons of air pollutants, providing an economic value of U.S. $\$ 3.8$ billion [24]. Increased expansion of urban vegetation can sequester substantial amounts of carbon [25]. Interestingly, they have capabilities to have a stronger effect on carbon budgets than trees outside cities. Urban forests involving public parks and gardens have significant amenity values with provision of relaxation and recreational opportunities. Generally these values fall outside market transactions and lack a market price. Therefore such non market benefits are ignored or sometimes underestimated by law makers while framing development options for the cities [19].

According to the Economics of valuing Ecosystem Services and Biodiversity (TEEB), the value of ecosystem services and biodiversity is a reflection of what we, as a society, are willing to trade off to conserve the natural resources. Economic valuation of ecosystem services and biodiversity can make explicit to society in general and policy making in particular, that biodiversity and ecosystem services are scarce and that their degradation and depreciation has associated costs to society. If these costs are not imputed, then policy would be misguided and society would be worse off due to misallocation of resources [26].

A number of studies have been undertaken around the world in measuring economic value of recreational sites like parks and gardens, forest reserves and other environmental assets. For instance, Desaigues and Dumingue [27] estimated the social benefits of biodiversity in Southwest France. Using open ended approach, they estimated Willingness to Pay (WTP) for the restoration program of the $70 \mathrm{~km}$ riparian forest. They found that the social benefit of the program exceeded its protection cost. Roy in 2003 [28] conducted a WTP survey in a ward of Kolkata Municipal Corporation for safe drinking water. They found that strong relationships can be exists between WTP and individual characteristics, such a sage, income, and education. Availability of UGS has great impact on the quality of life.

One study was carried out by Akbar, et al. [29] in Nehbandan, Iran, which investigates the effects of UGS on the quality of life of citizens and it was revealed that about
$50 \%$ of the citizens thinks that the availability of green spaces within the city can lead to reduction of environmental pollutants and elevation of the their lifestyle. Chaudhry conducted a study in 2013 in Chandigarh to value recreational benefits of urban forestry and he found that the mean WTP for the upgrading of existing parks and gardens and for creating new green spaces on the part of each rationally earning family residing in the city was discovered to be 2.18 USD per year for a period of five years, which converts to an annual recreational use value of city's urban forestry assets to 392,857 USD at 2002-03 prices, 2358 residents were interviewed for the study. Likewise this paper also undertakes WTP on the part of residents for conservation and management of parks and gardens.

Evaluation of green space literature highlights widespread use of the questionnaire method in generating data for studies that aim to discover the influence of green spaces on human wellbeing and the quality of life in urban contexts [30]. According to Hutchinson [31] the reason for doing questionnaire-based research is the flexibility, adaptability and costeffectiveness of the method in contrast to other approaches in generating data from large numbers of people with several backgrounds in a relatively short span of time. Jim and Chen [32] utilized this method to investigate resident perception and attitudes toward urban green space. Likewise, this study has utilized a semi-structured questionnaire that has covered social, economic, ecological aspects of urban green spaces. It has also measured the awareness level of user's regarding urban ecosystem terminologies (based upon their age groups). WTP for conservation and management of urban green spaces was also studied through questionnaire.

\section{Materials and Methods}

\section{Study Area}

Delhi, the capital of India, lies in the Gangetic plains, between $28^{\circ} 22^{\prime}$ to $28^{\circ} 24^{\prime} \mathrm{N}$ and $76^{\circ} 48^{\prime}$ to $77^{\circ} 23^{\prime} \mathrm{E}$ on the bank of river Yamuna. The state has total geographical area of 1483 square $\mathrm{km}$. Delhi has semi-arid climate, with very hot summers and moderate winters. According to ISFR, total forest cover in Delhi is 192.41 square $\mathrm{km}$ and total tree cover is $113 \mathrm{sq} . \mathrm{km}$, hence total tree and forest cover is 305.41 sq. $\mathrm{km}$ which is $20.22 \%$ of total geographical area [6]. Per capita Forest and Tree cover is $0.002 \mathrm{ha}$. Dominating soil type is alluvial (mainly shallow and dry) and annual temperature ranges between $3^{\circ} \mathrm{C}$ $45^{\circ} \mathrm{C}$, rainfall varies from $400-600 \mathrm{~mm}$. The study was carried out in three parks of Delhi: Lodi Garden, DDA 
District Park, and Kamala Nehru Ridge Park (Proposed Biodiversity Park).

Lodi Garden-the Park was developed during British Period and was inaugurated by Lady Willingdon on 9th April 1936. Due to its historical \& archeological importance, the park was named as Lodi Garden. It has area of 90 acres and is protected by Archaeological Survey of India and is managed by NDMC. According to tree census conducted in 2015 by NDMC, the total number of trees in the garden is 7,055 with 189 species. It is home to species like palm, olives, various medicinal species, flowering trees, exotic species. DDA District Park, Sector 11 , Dwarka- Dwarka zone is located in the South- West zone, is about a decade old and is maintained by DDA. Dwarka is divided into 29 sectors and our study site lies in $11^{\text {th }}$ sector. This park comes under Horticulture Division, Dwarka. The area of the park is approximately 20 Acre. According to a research conducted in Dwarka, the major tree species found are- Dalbergia sissoo (shisham), Syzygium cumini (jamun), Pongamia pinnata (karanj) etc. and it has homogenous distribution of tree girths. Majority of trees lies in the girth size class of 0-25 cm [33].

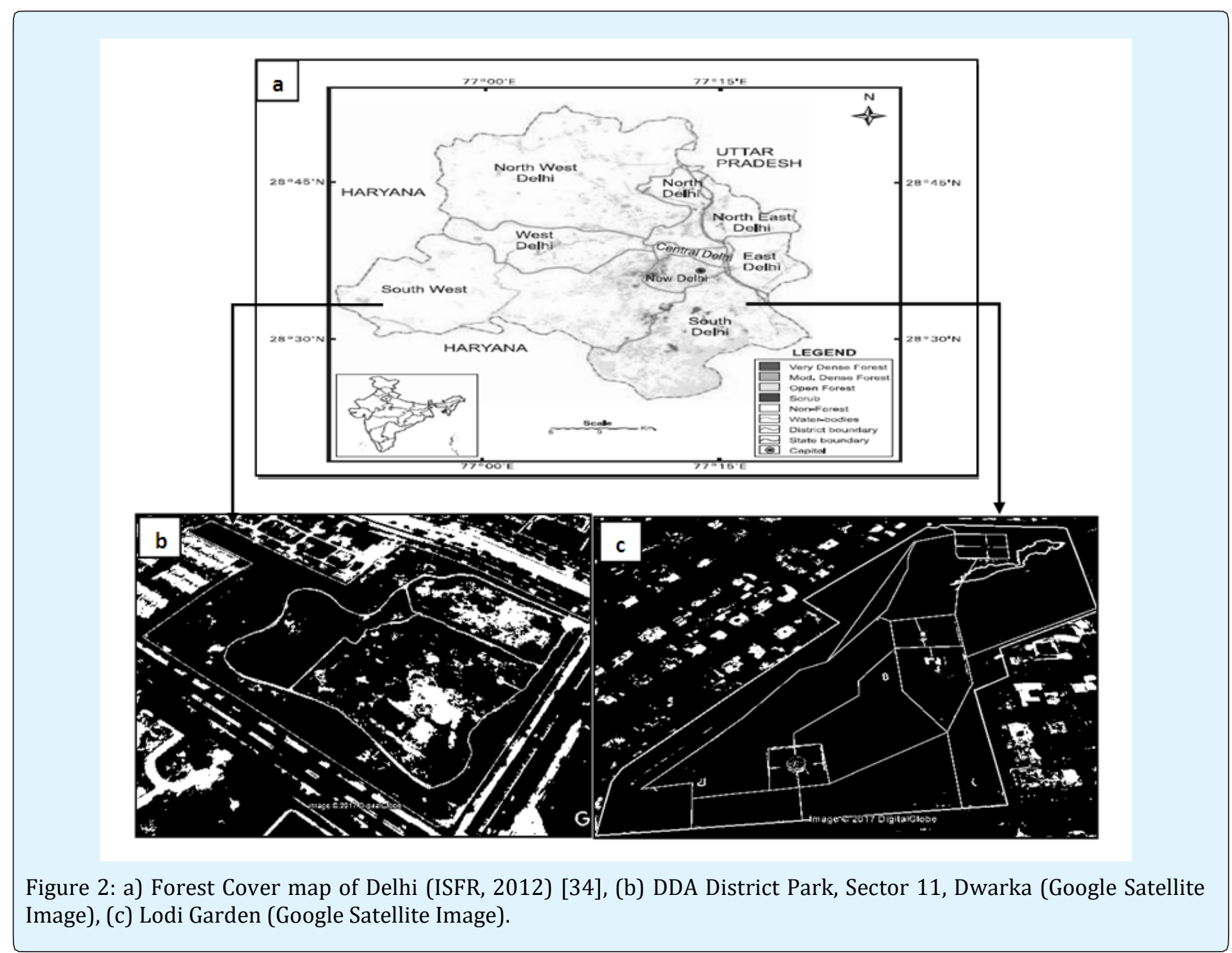

After India's Independence in 1947, Delhi exploded into the megacity it is today and the stress on the natural resources of the city increased manifold as a series of intrusions, legal and illegal, have devoured more and more area. The Ridge became prey to rampant 'urbanization' and other drivers of developmental impacts which included construction work, road widening, quarrying, garbage dumping and encroachments, and this 
led to swallowing up of large chunks of the Ridge by the city. With the birth of the forest wing in 1950, the Administration had taken up the planned work of managing the Ridges through norms of forestry. The Delhi Administration vide their notification dated 19.11.1958 appointed the Soil Conservation Officer (SCO) as Forest Officer and under his able auspices, the charge of management of both the Ridges was given to Development Department to maintain the Ridge with its natural status and keep encroachers at bay.

The Hon'ble Lt. Governor of Delhi ordered the transfer of the Northern Ridge to DDA in the year 1968, which was done on 30.11.1968, for maintenance and beautification. However, with the efforts of the then Development Commissioner, two nurseries namely Birla Temple and Kamla Nehru Ridge remained with the Forest Department, Delhi Administration. However, some encroachments were still occurring, so to preserve the Ridge as forest land, some non-profit organizations and citizen's groups working on environmental issues started protesting in 1979 against encroachments and destruction of the Ridge. In response to these efforts, Lt. Governor of Delhi declared 25 sites in the Northern, Central and SouthCentral Ridge as Protected Forests under the Indian Forest Act, 1927 on 10th April, 1980. Kamala Nehru Ridge has an area of 87 ha and is under the control and management of various agencies, which are mentioned below:

\begin{tabular}{|c|c|c|}
\hline S.no. & Managing agency & Area \\
\hline 1 & DDA (Kamala Nehru Ridge Park) & 73.00 ha. \\
\hline 2 & MCD (Hindu Rao Hospital) & 11.00 ha. \\
\hline 3 & Forest Department & 03.00 ha. \\
\hline & Total & 87.00 ha \\
\hline
\end{tabular}

Table 1: Control and management of various agencies on Kamala Nehru Ridge Park.

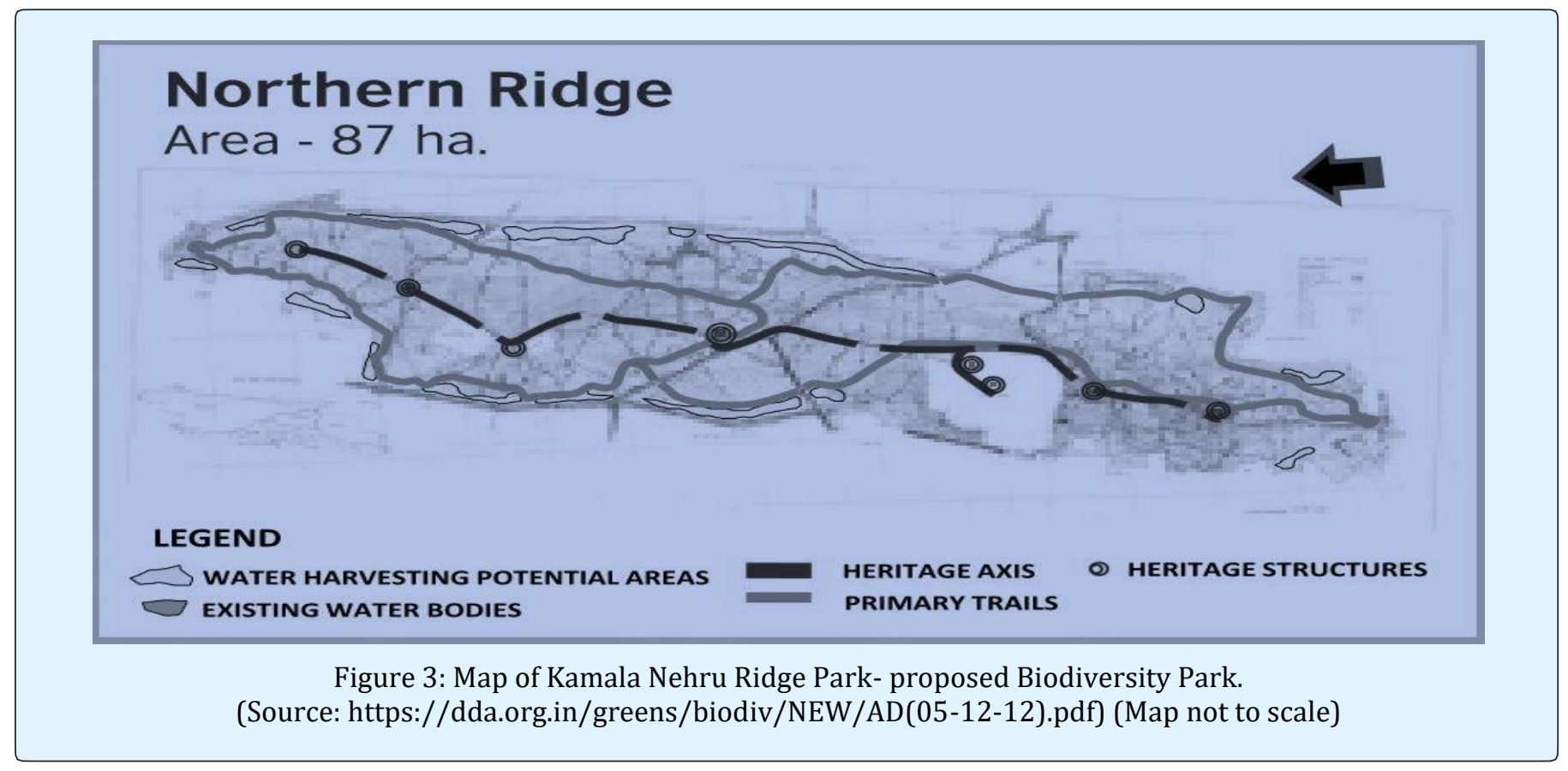

\section{Methodology}

\section{Sampling and Data Collection}

Data collection was done in the months of FebruaryApril 2011. The sampling methodology used in this study is quota sampling for parks, Lodi Garden and DDA Park, and random sampling for Kamala Nehru Ridge. In total
120 respondents ( 60 from each site), falling into three age groups, were interviewed in Parks and 52 were sampled in Kamala Nehru Ridge. The three age groups are: Young adults (18-35 Years), Middle adults (36-55 Years), and Old adults ( $>55$ years). Key informants, Horticulture officials and front line staff of NDMC and DDA were also interviewed. 


\section{Journal of Ecology \& Natural Resources}

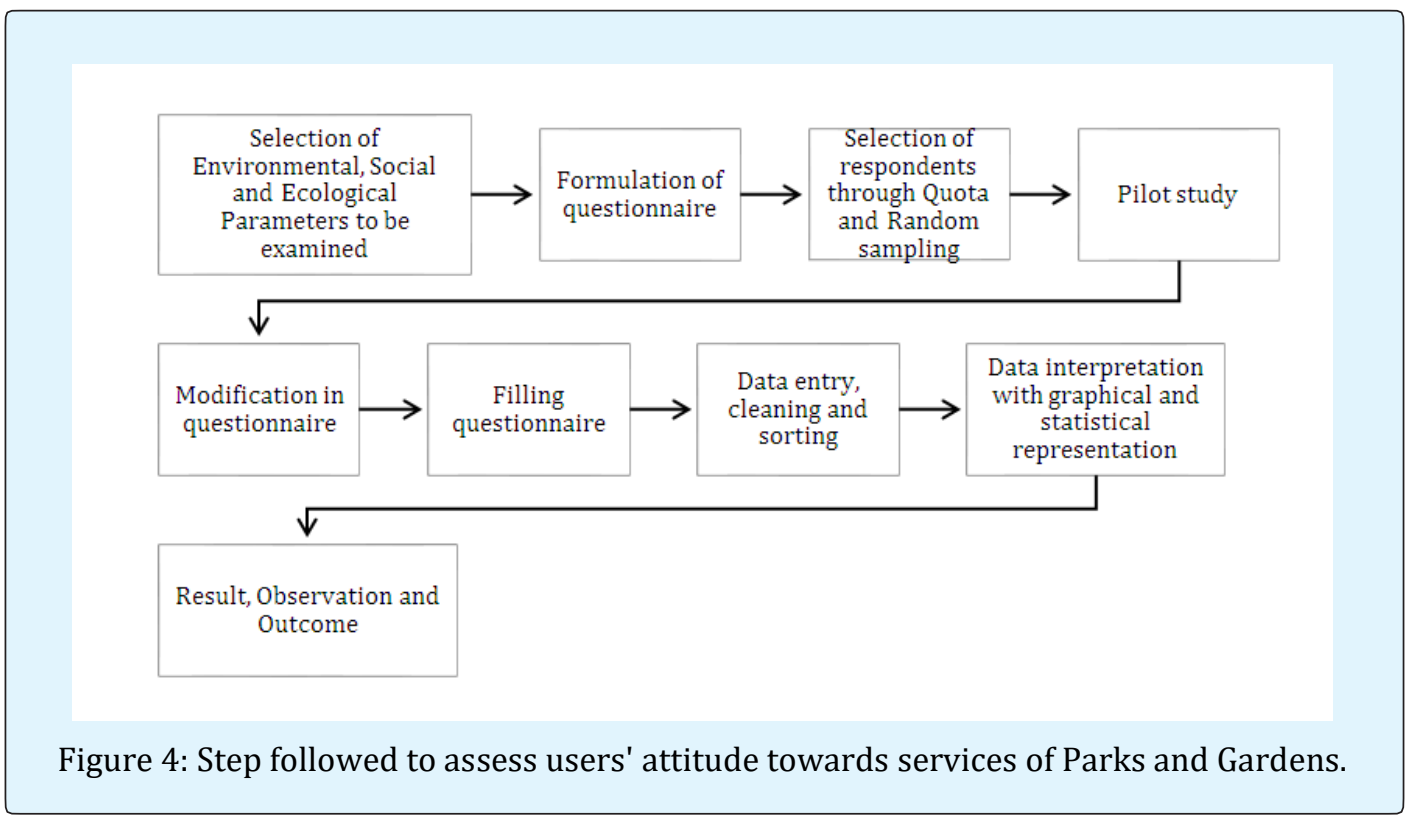

\section{Result Analysis and Discussion}

\section{Social}

The Social parameters basically dealt with the demographics, Respondent's background, and questions about his/her usage of the Urban Green Space. The Questions were also related to how the respondent saw the space and what were their issues and concerns regarding the park. A total of 120 respondents were interviewed in 2 parks (Lodi Garden and DDA Park, Sector 11, Dwarka). Both parks lie in a good residential area and with proximity to metro stations. As per authorities, average number of visitors (Local/tourist) is $11000 /$ day and 1500/day in Lodi Garden and DDA Sector 11 Park respectively. As per the analysis, most of the visitors (33\%) utilize urban parks to stay healthy.
According to them these places provide opportunities to work out for physical strength free of cost. For attracting more visitors most of the parks are incorporating open gym facilities in them. Another important utilization of the parks is to build social ties. Around $38 \%$ out of total $20 \%$ of the visitors who utilizes these places to build social ties is old aged adults. They spent considerable time in these places. On a monthly average around $54 \%$ of the visitors spend around 8-10 hours in parks for various purposes (Figure 5). Considerable amount of user's, 58\%, were strongly agreed with the fact that these places elevates their lifestyle and releases their stresses. Safety/security and accessibility are the most important parameters for the user's to visit a park. Around $28 \%$ of the visitors utilize these places only to hang out in the green environment with no other purpose.

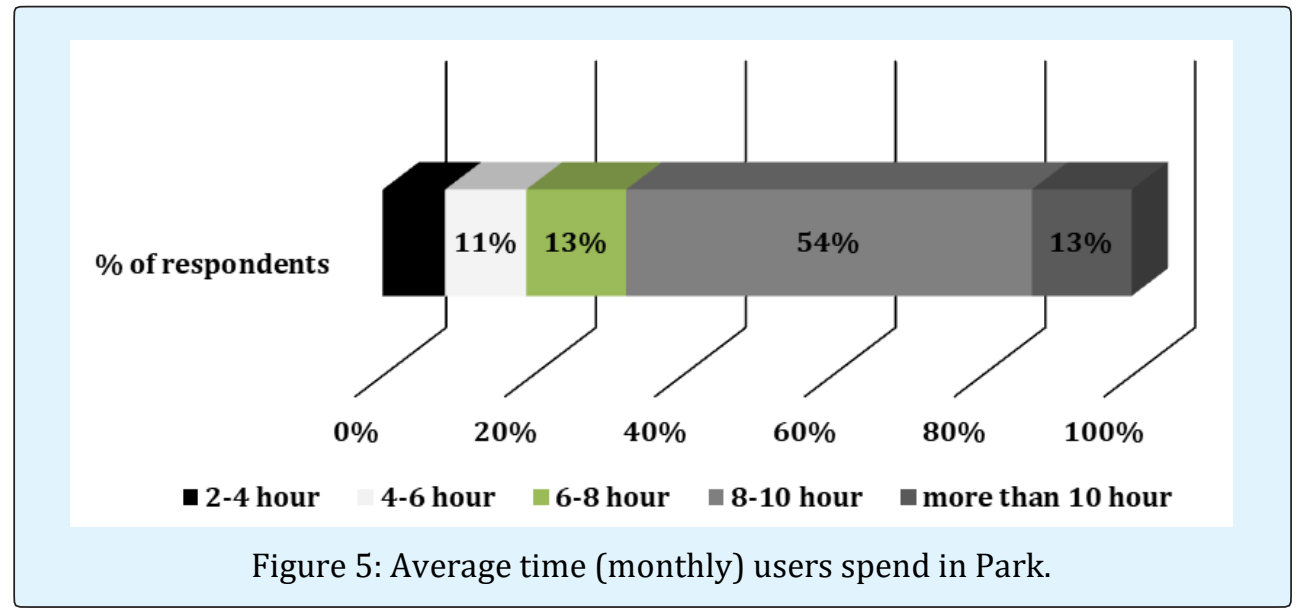

Bhattacharya P, et al. Assessment of User's Perception towards Urban Green Spaces: A Case Study of Delhi, India. J Ecol \& Nat Resour 2019, 3(1): 000156. 
For Kamala Nehru Ridge, 52 respondents that were surveyed (25 females and 27 males), most of the respondents were from the 35-45 age group followed by 45-60 years and 20-35 years. The respondents were asked about their frequency of usage of the park and it was revealed that more than $50 \%$ of the respondents came to the park daily and $33 \%$ used the park weekly. The respondents from the age group of 45-60 years and above, responded that they have been visiting this park for over 10 years, but the younger generation had recently started using the park therefore it had only been 2-6 years since they started visiting the Ridge.

More than half $(57 \%)$ of the respondents strongly agreed with the fact UGS affects their lifestyle positively while only $4 \%$ disagreed with this (Figure 6). Many researches support this finding. The most worthy impression of urban green spaces on cities is their environmental functions which is favorable to qualitative improvement of citizens [35]. As per the study conducted in Nehbandan city of Iran, the results shows that urban green areas play a significant part in reducing environmental pollution, increases social interactions, raises citizens morale and improves mental health which in turn results in improvement of living conditions for citizens [36].

\section{Urban green spaces elevate lifestyle}

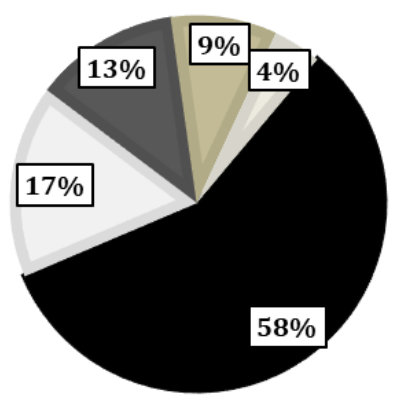

¿ Strongly Agree
Agree
— Undecided
Disagree
Strongly disagree

Figure 6: Agreement of respondents with the statement- UGS has positive impact their lifestyle.

\section{Ecological}

More than half of the users were strongly agreed with the fact that urban green spaces provide various ecosystem services to them. Around 65\% were strongly agreed with the statement that these places are helpful in recharging ground water. Nearly 52\% replied affirmatively on carbon sequestration and microclimate regulation service of urban parks and gardens. Very few users $(13 \%)$ were strongly agreed with resilient property of urban green spaces. Around $41 \%$ replied positively on the pollution absorption service of urban green spaces. Overall this section provides an insight that users are quite aware of ecosystem services provided by parks/gardens and other green spaces.

\section{Economic}

UGS carries a number of non-market or intangible benefits, which make a city healthy and perfect place to live. Recreation and aesthetic welfares are among such ecosystem services being generated by these resources. This study undertook some methods (Choice Modeling, Hedonic Pricing, and Contingent Valuation) and tried to convert the intangible benefits to monetary terms.

When users were asked if it is possible to convert the services provided by parks and gardens into monetary terms or any relationship exists between property value (land) and presence of urban parks and gardens in the proximity of property then most of them, around $86 \%$, couldn't decide whether the services are convertible to monetary terms or not. When respondents were offered two residential properties, one facing a busy street and other facing a well-furnished park, having huge difference (71385 USD) in their price, nearly $48 \%$ of the users were clearly ready to pay extra 71385 USD for an apartment which faces a well nurtured green space instead of one which faces a very busy road (keeping other features similar in both apartments). Around 78\% of the user's showed WTP visitation charges to urban parks and gardens for their better management and conservation. The mean WTP for the improvement and management of existing parks and gardens on the part of residents of the city was found to be 3.21 USD per year, 1.23 USD per month and 0.19 USD per day. Figure 7 shows percentage of respondents showing WTP entry fee/visitation charges for management of urban green spaces per day, per month and per year. This converts to an annual recreational value of 241.28 USD by $80 \%$ users who showed WTP (as around $19 \%$ of the users were willing to pay even more than 4.28 USD per annum). 


\section{Journal of Ecology \& Natural Resources}

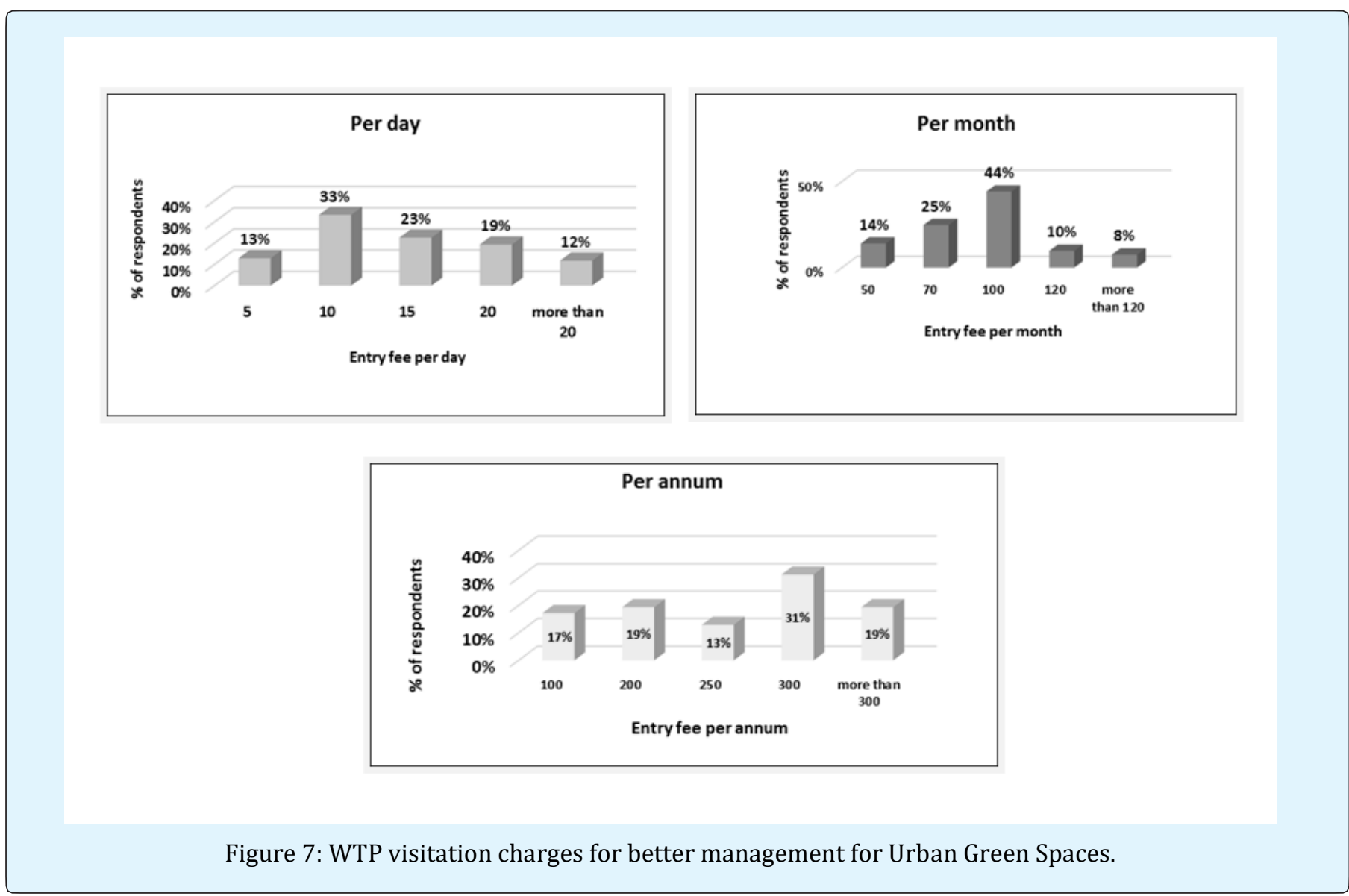

Around $67 \%$ of the respondents showed WTP green tax for the utilization of urban green spaces. Around 50\% of the respondents thinks that it is justifiable to pay 0.14 USD per day as entry fee to a park situated in a peaceful ambience instead a park situated near by a busy road (that doesn't charge any entry fee).Little more than half of the users showed priority to access to urban green spaces instead of an attractive job package. Around $49 \%$ of the users showed interest in high salary package or it can be said that individuals showed WTA (Willingness to Accept) compensation i.e. amount of money offered to the individuals by not allowing him/her to utilize a particular environmental asset i.e. parks/gardens or other green space of the city.

Most of the respondents (92\%) think that UGS encapsulates maximum benefits for urban poor and provides various livelihood opportunities to them by providing wood for stay shed, fuel wood for cooking, collect medicinal plants from open UGS etc. Around 7\% were not able to decide about these services of UGS while only $2 \%$ disagreed.

\section{Awareness Level of Respondents towards Urban Terminologies}

Various terminologies related to urban ecosystem were also asked to examine the awareness level of the respondents. Mean awareness of the respondents was $67 \%$. Surprisingly all three age groups showed similar average awareness level i.e. 67\%. Among young aged adults, maximum (38\%) has awareness level of range 60$80 \%$, middle aged adults and old aged adults also has similar range of awareness level for maximum respondents which is $35 \%$ and $38 \%$ respectively. There is no significant difference in their awareness level. The term with which almost everyone was aware of was "Urbanization" and "Urban Heat Island" was the least known terminology.

\section{Policy Implications: Need for institutionalizing Urban Forestry}

- The conservation and construction of various forms of green spaces has become part of urban planning, policy 
and legislation [37]. The urban green infrastructure related policies at various level of government must be re-evaluated and revised.

- National policies can mandate the carbon mitigation of urban green infrastructure as a principle to guide the development of long term urban carbon scenarios and identification of sustainable urban development strategies. At the provincial and municipal level, comprehensive operational legislative and administrative measures should be developed to integrate urban green infrastructure with traditional sectors to manage climate change mitigation.

- Specific policies might include creating new green spaces, maintaining existing green spaces, conserving natural lands through zoning control, and planting fastgrowing species that have long life spans and mature into enormous plants [38]. Government of Delhi has already taken several steps to boost up Delhi's green infrastructure. To have proper legal control, there is a specific act in the form of Delhi Preservation of Tree Act,1994 (DPTA,1994) [39] which is pertinent in the NCT of Delhi in respect of all the tree irrespective of its ownership and the ownership of the land on which it is standing.

- Studies involving quantifying and assessing urban environmental amenities like green spaces, water bodies, clean air etc. are truly lacking in India. Innate understanding of the ecosystem services generated by these assets can provide reasonable information for cost-benefit analysis of development projects contesting with such green assets.

- Municipalities or local bodies, who generally face deficiency of funds in developing countries, can utilize findings of such studies for generating more revenues [19].

\section{Conclusion}

It is appropriate to mention that surveys for evaluating non-market benefits of urban parks and gardens are more common and familiar to the western countries where rate of literacy is higher [19]. In current study, the respondents (mainly local) who were not familiar with the idea of valuation techniques were suspicious of the questions and they hesitated in providing personal information such as income, mode of travel, their WTP, choices etc. Yet some meaningful results are obtained from this study capable of representing user's perception towards various urban green spaces.

- More than half of the respondents showed WTP green tax and entry fee/visitation charges for the ecosystem services provided by the trees. Payment for Ecosystem Services (PES) in big urban areas has huge opportunities in recent future.

- They (respondents) considered accessibility to urban green spaces more important over money.

- Findings indicate that urban parks and gardens are part of their lifestyle. They prefer open gym facilities in green environment of parks over other gyms in built environment.

- Proximity and safety of the parks are very important factors in deciding number of visitors in a park.

- Nearly $37 \%$ visitors of the Lodi Garden use to spend 2.14 USD Per day to enjoy the features of this park which shows the importance of the amenities of the garden.

- More gardens and parks should be established in the proximity of residential societies wherever possible so that maximum users can take advantage of urban green spaces.

\section{Recommendations}

Urbanization at a speedy pace is a reality at present. Urban Forestry is an important causal factor in the cities for environmental enhancement, control of air and noise pollution, microclimatic modification and recreational purposes of the urban population. Following are some recommendations to improve the status of parks and gardens (UGS) in cities:

- More involvement of local residents in the planning process may provide them with a sense of place and guardianship over parks, contributing to greater use of parks and to higher levels of physical activity across residents.

- Guaranteeing that parks provide prospects for participation in different types of activity while serving the needs of different populations will be difficult for local governments and urban developers but this approach to planning and design is needed if more people are to be encouraged to use parks [40].

- Concept of urban green spaces should be integrated into urban development projects.

- Massive tree plantations drives are suggested to be taken up to increase green cover of Delhi from 20.59\% of geographical area to $33 \%$ in areas along avenues and public places.

- Authorities may charge nominal visitation charges or green tax for the utilization of urban parks and gardens. With this users might understand the importance of these places, and also it will generate revenue which can be utilized further for greening purpose or proper management. 
- The trees in the formal avenue planting should be planted in rows on either side of the road in a staggered manner. Urban Greening Guidelines (2014) [41] must be implemented thoroughly.

- Before the city enlarges further a proper plan for greening in the city especially with respect to land availability in the form of parks and gardens, forest patches and road side plantation should be in place.

- In addition to avoid illegal alteration of green cover of the city for taking up developmental works or otherwise a legal framework should be in place.

- Plan for urban forestry should be combined into overall planning of the urban areas in advance otherwise greening of the urbanized area becomes more challenging once the settlement takes place especially in categorizing the land for the same and in greening the same[42,43].

\section{Acknowledgement}

Authors thank Dean, USEM, GGSIPU, New Delhi, for providing support and encouragement for this work. We are thankful to the authorities of DDA Park and Lodi Garden for their cooperation during the study. This study did not use any specific grant from funding agencies in the public, commercial, or not-for-profit sectors.

\section{References}

1. United Nations (2014) Department of Economic and Socal Affairs, Population Division. World Urbanization Prospects: The 2014 Revision, Highlights (ST/ESA/SER.A/352).

2. Gupta HS, Okhandiar RR (2013) Policy and Legal Framework for Urban Green Space Governance in India.

3. United Nations (2016) Department of Economic and Social Affairs, Population Division. The World's Cities in 2016 - Data Booklet (ST/ESA/ SER.A/392).

4. Bhattacharya P, Nigam V (2010) Status Paper on Urban Forest and Biodiversity. Paper presented in the International Conference on Urban Forestry and Biodiversity organized by AFE, New Delhi, India.

5. Ulrika AS, Grahn P (2003) Landscape Planning and Stress. Urban Forest Greening 2(1): 1-18.

6. IFSR (2017) State of Forest Report 2017 executive summary.
7. Shanker VS, Pandey DN, Gupta AK, Ravindranath NH (2010) Climate change impacts, mitigation \& adaptation. Science for generating policy options in Rajasthan, India. RSPCB occasional paper No 2.

8. Delhi Parks and Garden Society (2017) Homepage.

9. Delhi city census data (2011).

10. Delhi Population (2017).

11. Sinha GN (2014) An Introduction to the Delhi Ridge. Department of Forests \& Wildlife Government of National Capital Territory of Delhi, New Delhi, pp: 154.

12. Agarwal R (2010) Fight for a Forest, Seminar Magazine 6: 13.

13. Profous GV, Loeb RE (1990) 'The Legal Protection of Urban Trees: A Comparative World Survey', J Environ Law 2(2): 179-192.

14. Costanza R, d'Arge R, De Groot RS, Farber S, Grasso M, et al. (1997) The value of the world's ecosystem service and natural capital. Nature 387: 253-260.

15. Escobedo F, Varela S, Zhao M, Wagner JE, Zipperer W (2010) Analyzing the efficacy of subtropical urban forests in offsetting carbon emissions from cities. Environ Sci Policy 13(5): 362-372.

16. McPherson EG (1992) Accounting for Benefits and Costs of Urban Green Space. Landscape and Urban Planning 22(1): 41-51.

17. Khan SM (2013) Principles of urban green space planning, published by the National Bureau of Organizations and Municipalities.

18. Azadi H, Ho P, Hafni E, Zarafshani K, Witlox F (2011) Multi-Stakeholder Involvement and Urban Green Space Performance. J Environ Planning Manag 54(6): 785-811.

19. Chaudhry P (2013) Valuing recreational benefits of urban forestry-A case study of Chandigarh city of India. Int J Environ Sci 3: 1785-1789.

20. Miller RW (1997) Urban Forestry: Planning and Managing Urban Green Spaces, $2^{\text {nd }}$ (Edn.), PrenticeHall, New Jersey.

21. Pankratz S, Young T, Cuevas-Arellano H, Kumar R, Ambrose RF, et al. (2007) The ecological value of 


\section{Journal of Ecology \& Natural Resources}

constructed wetlands for treating urban runoff. Water Sci Technol 55(3): 63-69.

22. DeNardo JC, Jarrett AR, Manbeck HB, Beattie DJ, Berghage RD (2005) Storm water mitigation and surface temperature reduction by green roofs. Transactions ASAE 48(4): 1491-1496.

23. Brenneisen S (2006) Space for urban wildlife: designing green roofs as habitats in Switzerland. Urban Habitats 4(1): 27-36.

24. Nowak DJ, Crane DE, Stevens JC (2006) Air pollution removal by urban trees and shrubs in the United States. Urban Forestry and Urban Greening 4(3-4): 115-123.

25. Pickett ST, Cadenasso ML, Grove JM, Groffman PM, Lawrence EB, et al. (2008) Beyond urban legends: An emerging framework of urban ecology, as illustrated by the Baltimore Ecosystem Study. Bioscience 58(2): 139-150.

26. De Groot R, Fisher B, Christie M, Aronson J, Braat L, et al. (2010) Integrating the ecological and economic dimension in biodiversity and ecosystem service valuation. In: Kumar P (Ed.), The Economics of Ecosystems and Biodiversity: Ecological and Economic Foundations. Earthscan, pp: 11-40.

27. Desaigues B, Dumingue A (2001) An estimation of the social benefits of preserving biodiversity. Int J Global Environ Issues 1(1): 73-86.

28. Roy J (2003) An economic analysis of demand for water quality: A case from Kolkata City, paper presented at the conference on Market Development of Water and Waste Technologies Environmental Economics, 30-31 ${ }^{\text {st }}$ October 2003, New Delhi.

29. Akbar K, Javadiyan M, Pasban V (2014) Evaluation of Urban Green Spaces and their impact on Living Quality of Citizens. J Civil Eng Urban 4(S): 89-95.

30. Lo AY, Jim CY (2010) Willingness of residents to pay and motives for conservation of urban green spaces in the compact city of Hong Kong. Urban Forestry Urban Greening 9(2): 113-120.
31. Hutchinson S (2004) Educational research and inquiry, qualitative and quantitative approaches. Continuum International Publishing Group, pp: 258.

32. Jim CY, Chen WY (2006) Perception and attitude of residents toward urban green spaces in Guangzhou (China). Environ Manag 38(3): 338-349.

33. Bhalla P, Bhattacharya P (2015) Urban Biodiversity and Green Spaces in Delhi: A case study of new settlement and Lutyens's Delhi. J Human Eco 51: 8396.

34. IFSR (2012) State of Forest Report 2013 executive summary.

35. Majnounian H (1995) Debates about the arks, promenades and green spaces, Tehran deputy of Municipal Services Organizations.

36. Kiani A, Javadiyan M, Pasban V (2014) Evaluation of urban green spaces and their impact on living quality of citizens: A case study of Nehbandan City, Iran. J Civil Eng Urban 4(S): 89-95.

37. Jim CY, Liu HHT (2000) Statutory measures for the protection and enhancement of the urban forest in Guangzhou city, China. Forestry 73(4): 311-329.

38. Gill SE, Handley JF, Ennos AR, Pauleit S (2007) Adapting cities for climate change: The role of the green infrastructure. Built Environ 33(1): 115-133.

39. Delhi Preservation of Trees Act (1994) Legislative Assembly of the National Capital Territory of Delhi.

40. McCormack GR, Rock M, Toohey AM, Hignell D (2010) Characteristics of urban parks associated with park use and physical activity: A review of qualitative research. Health and Place 16(4): 712-726.

41. Urban Greening Guidelines (2014) Town and Country Planning Organization, Ministry of Urban Development, Government of India.

42. Map of Kamala Nehru Ridge Park- proposed Biodiversity Park.

43. Urban Green Nation: Building the Urban Base. 